Article

\title{
The Identification of Factors Determining the Probability of Practicing Inland Water Tourism through Logistic Regression Models: The Case of Extremadura, Spain
}

\author{
Marcelino Sánchez-Rivero ${ }^{1}\left(\mathbb{D}, \mathrm{M}^{\mathrm{a}}\right.$ Cristina Rodríguez-Rangel $\left.{ }^{1, *} \mathbb{(}\right)$ and \\ Yakira Fernández-Torres ${ }^{2}$ D \\ 1 Applied Economic Analysis, Faculty of Economics and Business, University of Extremadura, Avda Elvas s/n, \\ 06006 Badajoz, Spain; sanriver@unex.es \\ 2 Department of Financial Economics and Accounting, Faculty of Business, Finance and Tourism, \\ University of Extremadura, Avda. de la Universidad, s/n, 10071 Cáceres, Spain; yakiraft@unex.es \\ * Correspondence: mcrisrod@unex.es
}

Received: 5 May 2020; Accepted: 7 June 2020; Published: 10 June 2020

check for updates

\begin{abstract}
Inland water tourism is put forward as a highly sustainable and attractive tourism product owing to its ability to generate economic development, raise awareness of respect for the environment, and contribute towards the diversification necessary to alleviate overexposure in coastal areas. For this reason, territories with sufficient expanses of water increasingly strive to create tourist products which allow them to enjoy the benefits associated with this type of tourism. The case of the region of Extremadura in Spain deserves special attention due to the abundant presence of lake resources which allows it to find an opportunity to stand out in inland water tourism and promote economic development. The initial objective of this research is the generation of knowledge of the demand currently existing in the territory. In order to do so, a logit regression model is used based on 4625 surveys collected in 2017. This model is later verified by means of a Chow test so as to analyze which factors influence the probability of practicing inland water tourism, paying attention to certain control variables such as the season or the tourist market. The results obtained have important implications for tourism managers and the establishment of a suitable development policy strategy.
\end{abstract}

Keywords: rivers; reservoirs; gorges; tourism; demand; Chow test; probability

\section{Introduction}

Given that it is one of the fastest growing economic sectors, tourism is increasingly being conceived as an indispensable commitment to the generation of wealth and economic growth, the protection of the environment, and the alleviation of poverty; all of which has made it a strategic and necessary part of the effort to comply with the 2030 Agenda for Sustainable Development approved in 2015 by the member countries of the United Nations. In addition, of the 17 Sustainable Development Goals that make up this Agenda, the role of tourism in Goal 13 (Climate Action) becomes vitally important given that coastal areas (which are considered to be major tourist attractions) are increasingly suffering the effects of climatic change. This is why a diversification strategy is necessary in which the promotion of inland tourist destinations [1] plays a prominent part.

In addition to the above, it should be considered that inland tourism generates important benefits for the receiving communities, among which can be mentioned the reduction in the economic inequality that exists between coastal and inland regions [2] and the scope of stable regional development [3], which explains why more and more inland territories are joining the tourist market [4]. Furthermore, 
this incorporation is stimulated by the appearance of new profiles of tourists interested in nature, active, and adventure tourism [5,6].

On the other hand, it is noteworthy that inland tourism still has considerable development potential, which implies a great opportunity that can be exploited by many territories. Specifically in the case of southwestern Europe where Spain is located, $50 \%$ of the inland regions are at an exploration stage while $52 \%$ of the coastal regions are stagnant [7]. At the same time, there is evidence that inland destinations with water resources also have an important competitive advantage owing to the importance which tourists attach to the aquatic systems of their destinations [8], the natural attraction humans feel for water resources [9], and the fact that in many cities and regions the channels, rivers or lakes are closely linked to their history and prosperity, playing an important role in the uniqueness of their environments [10]. Consequently, inland water tourism is put forward as an essential alternative so as to increase the flow of tourists to inland territories.

In this regard, if we examine the European context of interest to this study, it is noteworthy that its geography has an extensive network of rivers which have been connected over time through numerous channels, which has encouraged the growth of inland water tourism, mainly cruises. In addition, in recent decades, rivers have become more relevant among the choice of places for leisure and recreation activities, and in many cases their banks are the preferred locations for hotels and restaurants, given the attractiveness of their views to customers and the relaxing environment that is generated. There has therefore been a growing interest in exploring rivers and their surrounding areas and in converting open spaces close to the riverside to promote nature-based and tourist-type activities, which has a positive impact on the increase in income of related territories [11]. In this way, Europe is considered to be a favorable context for conducting studies on inland water tourism.

In addition, if we include lakes, these represent an essential element of recreation and tourism in many parts of the world, either because of their attractiveness in itself or because of the leisure activities they generate [12]. Thus in certain cases lake-based tourism can become one of the mainstays of the local economy [13].

Given the relevance of this type of tourism, studies have been carried out that are interested in the analysis of the profile of domestic water tourists Among these, we can cite Galloway [14], which examines the level of specialization and its relationship to motivation and place preferences in a sample of New Zealand kayakers. For their part, Albayrak and Caber [15] put the focus on rafting in the waters of the Koprulu Canyon in Turkey In turn, in Folgado et al. [16] the focus is on an analysis of the supply and demand of tourism based on nature activities for the protection of water ecosystems and the environment in the region of Extremadura, Spain. However, reflection on existing work indicates that this subject has been very rarely addressed in Spain.

Therefore, the importance and development potential of inland water tourism, the opportunity offered by the study of European geography, and the need to face the aforementioned deficiencies in the literature on the demand for this type of tourism in Spain are the reasons which justify the objective pursued in this applied research. Specifically, the objective of this research is to characterize the demand for inland water tourism in the region of Extremadura, Spain. To our knowledge, this would be the first study to analyze the factors determining the probability of practicing inland water tourism in that country and region, which corresponds to the intended contribution. The reason for selecting Extremadura lies in its availability of water resources, as it has the largest surface area of freshwater in Spain [17]. In addition, Extremadura is in a very favorable situation as an attractive destination for nature tourism, given that it has a valuable natural heritage supported by resources classified as natural areas of special relevance [18].

In order to fulfill this objective, a linear equation will be estimated using a logit model and based on surveys carried out on 4625 tourists by the Extremadura Tourism Observatory during 2017. The above will be complemented by a Chow test [19] in order to confirm the existence of structural change in the estimates deriving from seasonality and the type of market (Spanish or foreign). Among the results obtained, it stands out on the one hand that the probability of practicing inland water tourism in 
Extremadura is conditioned by the age of the tourist, the travel type, and the accommodation chosen. On the other hand, this probability is significantly different in the high season and in the low season and between Spanish and foreign markets.

Finally, this paper is structured in eight sections including this introduction. The following three sections develop the theoretical foundations on which the research is based. These sections refer to inland water resources as an alternative to sun and beach tourism (Section 2), to the revision of the literature on the demand for water tourism inland (Section 3), and the conditions that make Extremadura a region with a special attraction for this type of tourism (Section 4). Sections 5-7 cover the methodology used and the results obtained, the first being devoted to the logit model and the remainder to the analysis of the existence of structural change. Finally, Section 8 is intended to present the conclusions and implications.

\section{Rivers, Reservoirs and Gorges as an Alternative to Sun and Beach Tourism}

Tourism is characterized by constituting one of the fastest growing industries worldwide [20], which makes it a priority for some territories in order to achieve sustained strategic economic development, achieving a domino effect over other economic, social and cultural aspects [21].

Broadly speaking, inland tourism is understood to be any tourist activity carried out in non-coastal territories in which rural, natural and urban aspects coincide [4]. This activity is experiencing a positive trend which is favored by a series of changes attributable to both the level of demand and to supply factors. On the one hand, the appearance of new segments of tourist demand with a clear interest in nature, active, and adventure tourism stands out $[5,6]$. On the other hand, this is encouraged by an increase in the awareness of the territories regarding the possibilities which the development of tourist activity offers them to generate economic development, thus allowing the diversification of rural economies while creating new opportunities to generate wealth and employment [22-26]. The conjunction of these factors is materialized in the intense growth of alternative tourist activities to so-called mass tourism.

In addition, inland tourism is characterized by being able to strengthen the links between local communities and their natural resources, as their enhancement encourages an increase in awareness of the importance of their conservation [27-29]. It is therefore a highly sustainable form of tourism.

Considering the above benefits, it is not surprising that more and more inland territories are showing an interest in joining the tourist map by designing and offering an amalgam of increasingly specialized products which can be synthesized in the work carried out by Diez [4].

A case in point is inland water tourism in which all those tourist activities are included which uses a water system as the backdrop for their development (hiking trails, camping, nature tourism, etc.) [30]. In this case the expanse of water plays a subliminal role in attracting visitors to the destination [31,32]; or encourages specific activities (swimming, sailing, fishing, etc.) [33,34].

In an increasingly urbanized society, water is seen as an element of leisure and natural richness and, there is therefore a trend of its reassessment from a tourist point of view as a complement to other traditional uses. This allows it to take advantage of its potential to revitalize and develop tourist destinations around it, turning them into tourism products with a strong potential for attraction [16,35-37].

As territories which include expanses of water among their resources are aware of the benefits that this tourist attraction may entail for their development, they focus on developing tourist products around them which allow the sustainable exploitation of the territories of which they are a part. At a European level, some success stories can be mentioned.

The Great Lake of Alqueva on the border between Spain and Portugal is a good example of how lake resources can become a highly attractive tourist product. It is the largest artificial lake in Western Europe and has been created on the River Guadiana; it has a total area of $250 \mathrm{~km}^{2}$ and $1160 \mathrm{~km}$ of inland coast in both countries. Various projects have been developed around it such as that of "Alquevarural.com", which was created as a platform to facilitate the connection between supply and demand [38-40]. 
Lake Leman, also known as Lake Geneva, is another good example of a lake resource between two European countries, France and Switzerland, with a total surface area of $582 \mathrm{~km}^{2}$, of which $60 \%$ belongs to Switzerland and the remaining $40 \%$ to France. On the shores of the lake, towns and cities of great importance can be visited, such as Geneva, Nyon, Lausanne and Montreux. The surrounding area contains other important tourist resources such as the castles of Chillon and Ripaille, and also allows thermal tourism or visiting vineyards; all these activities have the lake as a backdrop [41,42].

Lake Garda or Lake Benaco, with a surface area of $368 \mathrm{~km}^{2}$, is the largest Italian lake and one of the most famous from a tourist point of view; its waters bathe the regions of Lombardy, Trentino-Alto Adige, and Veneto. On its banks there are endless towns, castles and monasteries and also interesting monuments and museums, which make the lake an important attraction for cultural tourism. Equally interesting are the possibilities it offers for sports tourism, with a wide range of activities including swimming, sailing, mountaineering, or hiking, and also for leisure tourism with its $50 \mathrm{~km}$ of beaches and theme parks [43].

The Sognefjord fjord stands out for being the longest and deepest in Norway with one of its arms, known as Naerodjorden, being particularly relevant as it is part of the UNESCO World Heritage network. In addition, it should be noted that it is currently in the process of being certified as a "sustainable destination". The activities it offers include cycling, excursions, and cruises through the fjord, hiking, mountaineering, and trekking on the glacier, among others; they make the lake an important destination for active nature tourism $[44,45]$.

All the cases presented are good examples of how to create a tourist destination based on the possibilities offered by having an expanse of water among the inventory of potential products. It can thus be observed in a practical manner how at a European level the territories that have taken advantage of this opportunity have been offering an amalgam of tourism products which, taking advantage of the integration of different resources, use their expanses of water as a backdrop for the designing of cultural, thermal or nature tourism products or the designing of products which require the resource itself for their practice and development, such as sports and active, leisure, and entertainment tourism.

In any case, all the examples mentioned reflect the interest shown by the territories in developing tourist products around their lake resources in order to shape an offer of activities which allows them to become sustainable tourist destinations, taking advantage of the various benefits that this type of tourism implies. In the following section, we review the situation of the demand for this new tourist type in order to focus on the subject of study of this research.

\section{The Demand for Inland Water Tourism: A Review of the Literature}

Decision-making on the type of tourist destination may imply the options of coastal tourism or inland tourism [46], the latter being that addressed in this research. In this sense, it is convenient to begin by highlighting that today there is a growing tourist demand apart from standardized tourism which seeks singular and differentiated elements, which is attracted by natural or rural environments that have not been transformed [47]; this reflects the great potential of inland tourism.

At the same time, there are several arguments to support the importance of promoting this type of tourism. To be precise, tourism has a greater positive impact on economic growth in inland areas than in coastal areas, a fact that contributes to reducing the inequality between regions as has been found in an analysis of China [2]. In addition, in countries with a highly seasonal tourism sector-as is the case in Spain, the context of interest in this study-the commitment to inland tourism and specifically rural tourism should be a way to achieve stable regional development, given that this tourism shows a pattern of sustained growth [3]. On the other hand, nature-based recreation can not only be an important mainstay of the economy of communities by attracting visitors but also represents a means of raising awareness of the use of natural resources. However, it is common to find that these communities lack information on the dimension and relevance of the recreational tourism that can be developed in their natural areas, which may explain the existence of a potential demand pending exploitation [48]. 
If we continue to focus our reflection on the demand for inland tourism, it is noteworthy that among its motivations, contact with nature was one of the most common reasons for visiting the Ribeira Sacra in Galicia, Spain [49]; this and the natural heritage represent the most important reasons according to a study of the network of the Schist villages in Portugal [50]. In addition, in the case of Australia, it was possible to verify the greater relevance of the natural characteristics of the destination with respect to its infrastructures as a tourist attraction [8]. In addition, Hernández et al. [51] confirm the importance of the natural and cultural aspects of the destination as a rural tourist attraction in Catalonia, Spain. In its turn, as to the characteristics of the candidates for nature-based tourism, it can be mentioned that the probability of participating in nature-based recreation activities decreases with age and increases with the level of income whether personal or family, all of which is based on research into the potential of the St. Johns River basin in Florida [48].

In addition to the above, if we take a closer look at the type of activity demanded by this profile of inland tourists, the results obtained by Borisova et al. [48] draw attention to the fact that among outdoor activities, those of the aquatic type-such as fishing, swimming or diving-are most common, which highlights the importance of inland water resources as a tourist attraction. This is also supported by a study on the importance of inland water systems for tourism and recreation in Australia, the results of which show that the clarity and quality of water and its accessibility are relevant aspects for attracting visitors [8]. These results are therefore in line with the argument maintained by Berezin [9] that humans are naturally attracted to the aquatic characteristics of places, which implies a significant enhancement of tourism in these areas; this attraction is also reflected in subsequent studies [52].

Following this argument, but limiting the discourse to the geographical context within which this study is set (i.e., Spain and Extremadura), two related studies should be mentioned. Firstly, a study was found that analyzes the tourist demand of the Ribeira Sacra, one of the destinations with the greatest inland tourism potential in Galicia and sustained by the mighty Miño and Sil rivers [49]. Among its results, it is noteworthy that the third activity carried out most frequently by visitors was that related to the use of aquatic resources, which is making boat trips ( $81.7 \%$ of cases). As far as Extremadura is concerned, a study provides data on the preferences of rural tourism candidates in one of the Extremadura provinces (Cáceres) in the form of an analysis of the tourist potential of the city [53]. To be precise, the surveys carried out by these authors showed that the presence of natural pools was the most attractive element in more than $80 \%$ of the responses. At the same time, from the territorial analysis carried out to detect rural destinations with the greatest tourist potential, it follows that the most attractive ones are those with watercourses from the mountains and natural pools.

At once, if we pay attention to the characteristics that predominate in the profile of the candidate for inland water tourism, we can mention the study of Albayrak and Caber [15], which concentrates its analysis on tourists who went whitewater rafting during a day of their vacation in the Koprulu Canyon (Antalya, Turkey) in order to ascertain their motivations for carrying out this activity. Among the results obtained it is noteworthy that most of the participants were single (55.6\%), men (59.1\%), private sector workers $(44.2 \%)$, university undergraduates $(45.2 \%)$, aged $18-34(50.9 \%)$, accompanied by a relative $(57.2 \%)$, and had not had a similar previous experience $(71.3 \%)$. On the other hand, the responses obtained confirm that the most important motivations for carrying out this activity were gaining a sense of belonging, challenging abilities, enjoying, developing skills, being active, and maintaining and developing physical fitness. Folgado et al. [16] carried out a survey of visitors to water tourism establishments in Extremadura, Spain with the following findings: the majority are women $(57.6 \%)$, over 55 years of age (59.8\%), from other Spanish regions (56.5\%) and with higher education $(68.5 \%)$; the most popular experience are visits to thermal centers. The proportion of foreigners $(1.1 \%)$ is negligible. Regarding the perceptions expressed, the author highlights that water-based tourism experiences have health benefits. However, it is worth mentioning that although this research has been carried out in the region to be addressed in this study, there are clear differences between the two, since the aforementioned author focuses on the role of nature-based tourism activities for the protection of water ecosystems and the environment on a supply and demand analysis. 
As for the remainder of the studies reviewed, generally not specifically addressed the profile of the tourist of interest. This can be verified in the case of Hadwen et al. [8], whose analysis was carried out from the supply side, i.e., through interviews with managers, representatives of institutions, and tour operators. In the study by Borisova et al. [48], the questionnaire focused on recreation based on nature in a general sense and not exclusively of an aquatic type. The situation is similar in the approach of Carballo-Meirino et al. [49], who concentrated their attention on visitors to the destination in general and not only on those interested in enjoying aquatic resources. In addition, Osnin and Abdul-Rahman [13] focus on navigation practices on Lake Kenyir in Malaysia, which attracts owing to various interests rather than merely tourism.

\section{4. "Extremadura Is Water": A Slogan That Defines a Tourist Differentiation Factor in an Inland Region}

Extremadura is an inland region located in the SW of the Iberian Peninsula which consists of the two largest provinces in Spain: Cáceres and Badajoz; the total surface area of the region is $41,633 \mathrm{~km}^{2}$. It is a region characterized by a low level of economic development, with agrarian-livestock activities predominating in its economy; it ranks as the Spanish region with the lowest GDP per capita [54]. In addition, this situation is compounded by a high unemployment rate, which reached $23.48 \%$ in the fourth quarter of 2019 [55]. Faced with this scenario, the region has seen fit to create new productive activities among which stands out a firm commitment to strengthen its tourism sector. As for the availability of existing resources in the region, it is noteworthy that it has the largest surface area of freshwater in the country with a total of $1500 \mathrm{~km}$ of coastline [17], which places it in an unbeatable position in order to constitute the benchmark of this tourist type. Figure 1 shows the spatial distribution of all its resources for the development of inland water tourism. Tourism managers in the region are not unaware of this situation and have therefore developed different tourism campaigns with their ultimate goal being the enhancement of the lake resources of the region as a distinctive feature, as is the case with the campaign started in 2016, "Extremadura is Water". The purpose of this campaign was to publicize the variety of resources available to the region in relation to different expanses of water and the possibilities that these provide for carrying out tourist activities.

One of the actions of this campaign is the creation of the "Extremadura Network of Natural Bathing Areas", i.e., the inventory of the variety of lake resources existing in the region, which gives detailed information on their location and on the services available in each of them. This inventory is updated annually and in its most recent version of 2019 we find that the region has a total of 52 bathing areas in its two provinces, 40 of which are located in Cáceres province and the remaining 12 in the province of Badajoz. Natural pools and gorges, modern spas, reservoirs where you can fish and practice water sports, cruises, and river beaches and reservoir beaches, among others, constitute the main resources on which the offer of the existing tourist products in the region is based.

It should be noted that, in order to reinforce the potential of the region's lake resources, to become a benchmark in this typology, the fact that the region has two of the only three inland beaches that bear the Blue Flag (recognized distinctive quality at European level), including the Costa Dulce Beach in Orellana la Vieja (Badajoz) which has held this flag for 10 years consecutively. The beach in Orellana was joined in 2019 by the San Blas Beach located in Cheles (Badajoz province), which won this distinction for the quality of its waters and its facilities for the first time in that year and hopes to continue to hold it for years to come [56].

In the same way and from an academic point of view, the interest in promoting the region as a benchmark in this sector is supported by the appearance of a series of studies with the ultimate purpose of generating knowledge on the existing water resources in the region and their exploitation possibilities as tourist resources. 


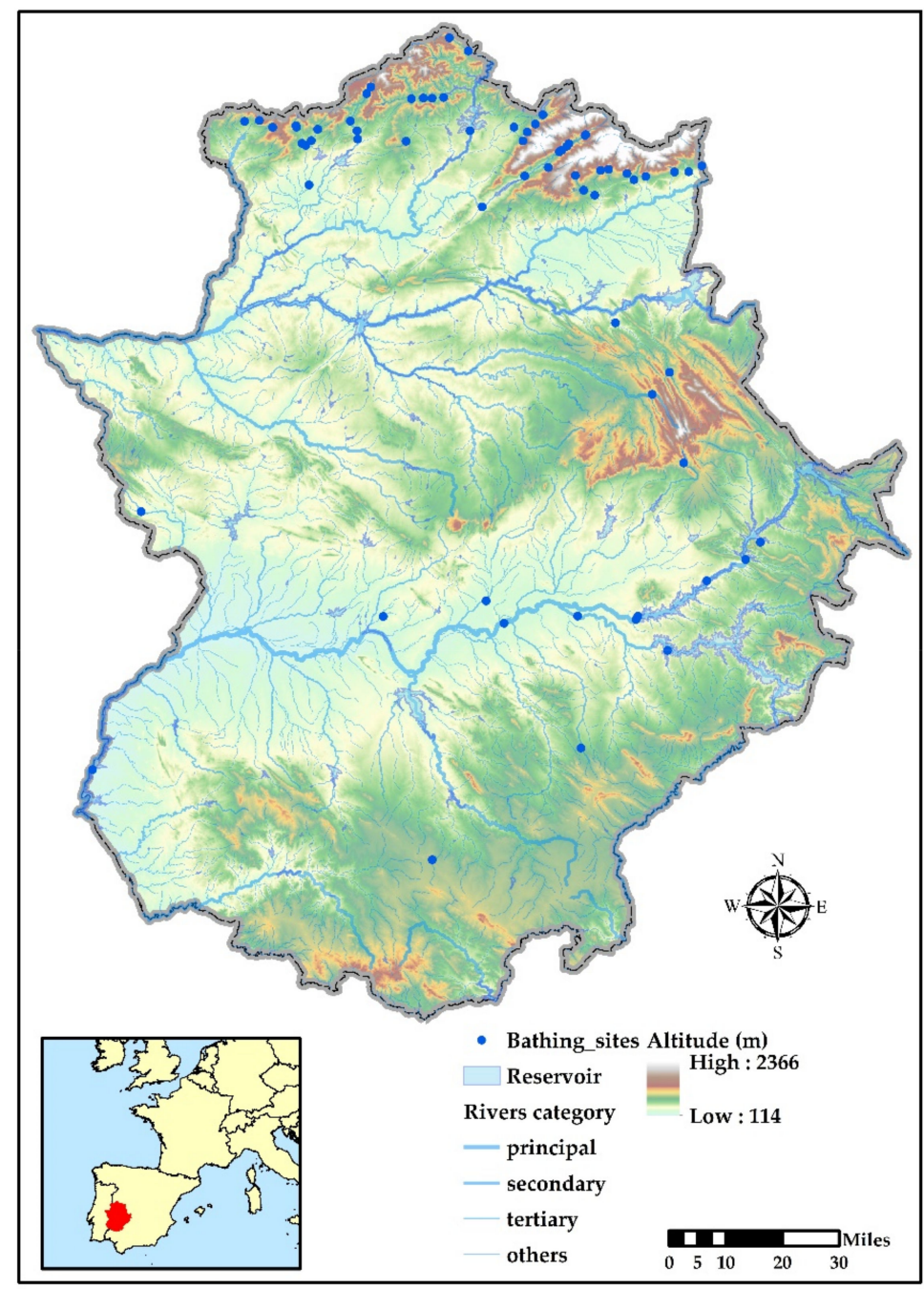

Figure 1. Spatial distribution of resources of inland water tourism in Extremadura (Spain).

Andrades [18] carried out a study to synthesize the main steps followed in the following of a tourist planning process in the vicinity of the La Serena reservoir, detailing the possibilities of transforming the natural resource into a tourist product. To do this, she performed a SWOT analysis (Strengths, Weaknesses, Opportunities and Threats) to serve as the basis for this process. This analysis includes a study focused on characterizing demand by conducting 317 surveys of tourists in the territorial area around the reservoir. A couple of years later, Andrades [57] carried out a study on the strategic planning of another of the lake resources of the region, the hinterland of Lake Alqueva. From the results obtained, she was able to differentiate three groups of tourists which she classifies as follows: family, active and sybaritic based on a series of sociodemographic characteristics, the available budget, and the type of activities carried out at the destination. Once this classification is drawn up, different tourist packages associated with the preferences of each of them are proposed.

Franco and Zhu [58] analyzed the current water resources of the region, determining that most of them are currently devoted to agricultural activities. They however point out the possibilities of giving them more sustainable and profitable uses as exploitation for the carrying out of tourist activities.

Subsequently, Sánchez, et al. [59] focused on analyzing the tourist demand for a specific type of inland water tourism, i.e., spa tourism. From the results obtained they were able to differentiate three groups of tourists: the unmotivated, the multi-motivated and the half-motivated; depending on the motivation indicated by tourists to visit a spa. In addition, they characterized each of these groups according to their age, educational level, income, type of accommodation selected, group size, 
and repetition of the visit, which are shown as the sociodemographic characteristics with the greatest capacity for distinguishing between the different motivational patterns.

In addition, Campesino [60] performed an analysis of the existing water resources on the "Raya Ibérica" border, which separates the two countries of the peninsula (Spain and Portugal). In it he describes the different expanses of water that the two cross-border products of Parque Natural Tajo and Parque Temático Natural Alqueva share as a natural border, which are those located in the region of Extremadura. Among its main conclusions, the contrast between their potential and the low level of development of the existing tourist products stands out in both cases.

Finally, Folgado-Fernández, et al. [16] aimed to explore the current tourist use of the aquifer systems of the region to determine whether these practices have the potential to generate new sensitivities of the value of water and its importance in socioeconomic development, while increasing awareness of the need for environmental conservation.

All these contributions have served as a basis for increasing our knowledge of the region's water resources and also for describing the profile of demand associated with some specific tourism types or that associated with certain territories. To date, however, as far as the authors are aware, no study has been carried out to generate knowledge about the water tourist in the region considering the entire territory.

\section{Data and Methodology}

\subsection{Description of Data}

The data that will serve to analyze the profile of water tourism demand in Extremadura have been obtained from the Extremadura Tourism Observatory. More specifically, the survey carried out in the network of tourist offices in the region during 2017 has been used to know the profile of the tourist who visits the region. Tourists who were part of the survey were randomly selected by the staff of these tourist offices. In addition to including issues related to gender, nationality, age range, the people accompanying the tourist on the trip, the type of accommodation chosen for the night or the assessment of various tourist services in the area visited, one of the questions of the survey referred to the type of tourist activity carried out during the visit, one of them being inland water tourism. In this way, and after carrying out a purification process of the original database, the final sample of 4625 tourists has been obtained, which is the one that has been used to estimate the logit model. Of this final sample, 4146 surveys correspond to national tourists ( $89 \%$ of the total) and 479 surveys correspond to foreign tourists ( $11 \%$ of the total) - a distribution that corresponds approximately to the distribution by nationality of the global tourism demand of Extremadura over the years (85\% domestic tourists; $15 \%$ foreign tourists). The distribution of the global sample by tourist season is as follows: 3018 tourists interviewed in high season and 1607 tourists interviewed in low season.

According to estimates from the Extremadura Tourism Observatory, the number of tourists that practice river, gorges and reservoir tourism in the region each year es about 439,000. This means that the analyzed sample represents around $0.25 \%$ of the total tourist population of Extremadura and around $1 \%$ of inland water tourists. In any case, the high sample size (4625) guarantees the robustness of the statistical results obtained in this paper.

Additionally, the practice (or not) of water tourism in the region has a binary nature, depending on whether the tourist has indicated (or not) the option of practicing this activity during their stay in Extremadura. Finally, the categorical nature of the variables included in the survey that can facilitate the definition of a profile of this type of tourists (nationality, type of accommodation, type of travel, age segment, etc.) requires the use of dichotomous explanatory variables (as many for each analyzed characteristic as categories considered in the survey minus one). Other variables (those related to the assessment of tourist services) can be considered as scale variables and have been introduced as such in the statistical model detailed below as explanatory variables of the probability of practicing water tourism. 


\subsection{Methodology for Estimating the Probability of Practicing Water Tourism in Extremadura}

In order to estimate the probability of practicing water tourism in Extremadura, a regression analysis has been used in which the dependent variable $\left(Y_{i}\right)$ is a dummy variable which will have a value of 1 if the tourist has practiced tourism in rivers, water reservoirs or gorges located in Extremadura, and a value of 0 if the reverse is true. Given the binary nature of this dependent variable, the following binary logistic regression model (or logit model) has been proposed:

$$
\mathrm{P}\left(\mathrm{Y}_{\mathrm{i}}=1\right)=\frac{\exp (\mathrm{z})}{1+\exp (\mathrm{z})}
$$

in which

$$
\begin{gathered}
\mathrm{z}=\beta_{0}+\beta_{1} \mathrm{GEN}_{\mathrm{i}}+\beta_{2} \mathrm{AG}_{\mathrm{i}}+\beta_{3} \mathrm{AG}_{\mathrm{i}}+\beta_{4} \mathrm{COMP}_{\mathrm{i}}+\beta_{5} \mathrm{COMP}_{\mathrm{i}}+ \\
\beta_{6} \mathrm{H} 1_{\mathrm{i}}+\beta_{7} \mathrm{H} 2_{\mathrm{i}}+\beta_{8} \mathrm{H} 3_{\mathrm{i}}+\beta_{9} \mathrm{VAL}_{2} \mathrm{ALOJ}+\beta_{10} \mathrm{VAL}_{\mathrm{i}} \mathrm{REST}_{\mathrm{i}}+\beta_{11} \mathrm{VAL}_{\mathrm{EMP}} \mathrm{EM} \\
+\beta_{12} \mathrm{VAL}_{\mathrm{N}} \mathrm{NAT}_{\mathrm{i}}
\end{gathered}
$$

in which $\mathrm{P}\left(\mathrm{Y}_{\mathrm{i}}=1\right)$ represents the probability that the tourist $i$ practices water tourism in Extremadura, and in which the explanatory variables of the model can be grouped in three main categories:

a. Sociodemographic variables:

GEN: gender $(1=$ male; $0=$ female $)$.

AG1: age $(1=35$ years or less; $0=$ other $)$.

AG2: age ( $1=$ between 35 and 55 years of age; $0=$ other). Note: Over 55 years of age $(\mathrm{AG} 1=\mathrm{AG} 2=0)$.

b. Variables of trip characterization:

COMP1: type of travel $(1=$ as a couple or with family; $0=$ other $)$.

COMP2: type of travel ( $1=$ with friends or in a group; $0=$ other). Note: Alone (COMP1 $=$ COMP2 $=0$ ).

H1: type of lodging selected for overnight stay $(1=$ hotel; $0=$ other $)$.

H2: type of lodging selected for overnight stay ( $1=$ rural lodging; $0=$ other $)$.

H3: type of lodging selected for overnight stay $(1=$ apartment, campsite, or hostel; $0=$ other $)$.

Note: other lodgings $(\mathrm{H} 1=\mathrm{H} 2=\mathrm{H} 3=0)$.

c. Variables of assessment of destination:

VAL_ALOJ: assessment on a scale of 0 to 10 points of the lodging offer.

VAL_REST: assessment on a scale of 0 to 10 points of the restaurant offer.

VAL_EMP: assessment on a scale of 0 to 10 points of the tourism activity company.

VAL_NAT: assessment on a scale of 0 to 10 points of the conservation of the natural heritage.

With the inclusion of sociodemographic, trip characterization, and destination assessment variables in model (1), we are trying to identify the variables that condition (or that could condition) the probability of tourist visits that need to be estimated.

Table 1 presents a descriptive summary of the sample of tourists based on the variables previously described. 
Table 1. Sample values of variables (endogenous and exogenous) used in the logit model (1).

\begin{tabular}{|c|c|}
\hline $\begin{array}{c}\text { Practice Water Tourism in Extremadura: } \\
\text { Yes: } 26.3 \% \\
\text { No: } 73.7 \%\end{array}$ & $\begin{array}{c}\text { Assessment of Lodging Offer (VAL_ALOJ): } \\
\text { Mean: } 8.302 \\
\text { Median: } 8.000 \\
\text { Mode: } 8.0 \\
\text { Std. deviation: } 1.312 \\
\text { Skewness: }-0.902 \\
\text { Kurtosis: } 2.848\end{array}$ \\
\hline $\begin{array}{c}\text { Gender: } \\
\text { Male (GEN = 1): } 48.1 \% \\
\text { Female }(\mathrm{GEN}=0): 51.9 \%\end{array}$ & $\begin{array}{c}\text { Assessment of Restaurant Offer (VAL_REST): } \\
\text { Mean: } 8.257 \\
\text { Median: } 8.000 \\
\text { Mode: } 8.0 \\
\text { Std. deviation: } 1.284 \\
\text { Skewness: }-0.844 \\
\text { Kurtosis: } 2.687\end{array}$ \\
\hline $\begin{array}{c}\text { Age: } \\
35 \text { years or less }(\mathrm{AG} 1=1): 19.9 \% \\
\text { Between } 35 \text { and } 55 \text { years }(\mathrm{AG} 2=1): 55.6 \% \\
\text { Over } 55 \text { years (AG1 = AG2 = 0): } 24.5 \%\end{array}$ & $\begin{array}{c}\text { Assessment of Tourism Activity Companies } \\
\text { (VAL_EMP): } \\
\text { Mean: } 7.816 \\
\text { Median: } 8.000 \\
\text { Mode: } 8.0 \\
\text { Std. deviation: } 1.587 \\
\text { Skewness: }-0.958 \\
\text { Kurtosis: } 2.467\end{array}$ \\
\hline $\begin{array}{l}\text { Type of Travel: } \\
\text { As a couple or with family }(\text { COMP1 }=1): 71.8 \% \\
\text { With friends or in a group }(\text { COMP2 }=1): 20.2 \% \\
\text { Alone }(\text { COMP1 }=\text { COMP2 }=0): 8.0 \%\end{array}$ & $\begin{array}{l}\text { Assessment of Conservation of Natural Heritage } \\
\text { (VAL_NAT): } \\
\text { Mean: } 8.505 \\
\text { Median: } 9.000 \\
\text { Mode: } 8.0 \\
\text { Std. deviation: } 1.183 \\
\text { Skewness: }-0.750 \\
\text { Kurtosis: } 1.416\end{array}$ \\
\hline $\begin{array}{c}\text { Type of Lodging Selected for Overnight Stay: } \\
\text { Hotel }(\mathrm{H} 1=1): 40.8 \% \\
\text { Rural lodging }(\mathrm{H} 2=1): 14.9 \% \\
\text { Apartment, campsite or hostel }(\mathrm{H} 3=1): 13.6 \% \\
\text { Other lodging }(\mathrm{H} 1=\mathrm{H} 2=\mathrm{H} 3=0): 30.7 \%\end{array}$ & \\
\hline
\end{tabular}

The logit model [61-64] has been frequently used in the field of tourism research. For example, it has been used for issues as diverse as the identification of the determinant factors of innovation in tourism [65,66], establishing space-time relations between hotels in urban tourism destinations [67], determining the influence of High Speed Rail on the probability of returning to visit a destination [68], studying the consumption of local food in rural tourism [69], analyzing the behavior of the tourist in terms of his consumption of certain products [70], analyzing air quality in museums [71], and determining the predictive factors of the tourist's loyalty to a destination [72]. It is therefore a widely contrasted methodology in the field of tourism research.

\subsection{Methodology for Testing the Presence/Abcense of Structural Change}

The test for structural change known as the Chow test [19] is typically used with conventional regression models to determine if when a model is divided into two subsamples the model parameters are stable. In a conventional regression model, this Chow test includes an F statistic in which the sum of the squares of the errors of the model estimated based on the total sample (restricted model) are compared with the sum of the squares of the errors of the models estimated based on each subsample (non-restricted model). 
However, when the estimated regression model is a binary logistic regression model, as in this case, the Chow test is conducted in the form of a likelihood ratio test between the restricted (pooled) logit model (model (1)) and the non-restricted logit model. This last model defines the $\mathrm{z}$ function as follows:

$$
\begin{aligned}
& \mathrm{z}=\beta_{0}+\beta_{1} \mathrm{GEN}_{\mathrm{i}}+\beta_{2} \mathrm{AG}_{\mathrm{i}}+\beta_{3} \mathrm{AG} 2_{\mathrm{i}}+\beta_{4} \mathrm{COMP}_{\mathrm{i}}+\beta_{5} \mathrm{COMP}_{\mathrm{i}} \\
& +\beta_{6} \mathrm{H}_{1}+\beta_{7} \mathrm{H} 2_{\mathrm{i}}+\beta_{8} \mathrm{H} 3_{\mathrm{i}}+\beta_{9} \mathrm{VAL}_{-} \mathrm{ALO} \mathrm{I}_{\mathrm{i}}+\beta_{10} \mathrm{VAL}_{-} \mathrm{REST}_{\mathrm{i}}+\beta_{11} \mathrm{VAL}_{-} \mathrm{EMP}_{\mathrm{i}}+ \\
& \beta_{12} V_{\text {VAL_NAT }}+\beta_{13} D_{i}+\beta_{14} G_{-} N_{i} \times D_{i}+\beta_{15} A_{1} 1_{i} \times D_{i}+\beta_{16} A 2_{i} \times D_{i} \\
& +\beta_{17} \mathrm{COMP}_{\mathrm{i}} \times \mathrm{D}_{\mathrm{i}}+\beta_{18} \mathrm{COMP} 2_{\mathrm{i}} \times \mathrm{D}_{\mathrm{i}}+\beta_{19} \mathrm{H} 1_{\mathrm{i}} \times \mathrm{D}_{\mathrm{i}}+\beta_{20} \mathrm{H} 2_{\mathrm{i}} \times \mathrm{D}_{\mathrm{i}}+\beta_{21} \mathrm{H}_{\mathrm{i}} \times \mathrm{D}_{\mathrm{i}}+ \\
& \beta_{22} V_{\text {VAL_ALOJ }} \times D_{i}+\beta_{23} \text { VAL_REST }{ }_{i} \times D_{i}+\beta_{24} V_{2 A L} E M P_{i} \times D_{i} \\
& +\beta_{25} \text { VAL_NAT }{ }_{i} \times D_{i}
\end{aligned}
$$

in which the $D_{i}$ variable is a control variable which takes the value of 1 in the case of the presence of a certain characteristic and 0 if the characteristic is absent.

In our case, and given the fact that the output of the Gretl results gives the logarithm of the Log-likelihood function, the contrast that has been used is the log-likelihood ratio test between both models as shown in the following equation:

$$
\mathrm{D}=-2\left[\log \left(\Lambda_{1}\right)-\log \left(\Lambda_{2}\right)\right]
$$

in which $\log \left(\boldsymbol{\Lambda}_{1}\right)$ is the logarithm of the log-likelihood function of the restricted model (model (1)) and $\log \left(\boldsymbol{\Lambda}_{2}\right)$ is the logarithm of the log-likelihood function of the non-restricted model (model (2)).

Wilk [73] demonstrates that the D statistic follows an asymptotic $\chi^{2}$ distribution with df2 - df1 degrees of freedom, in which df1 and df2 represent, respectively, the degrees of freedom of the models (1) and (2). If the $p$-valor associated with this D statistic is lower than the level of significance, the presence of a structural change may be admitted and it would therefore be possible to conclude that significant differences exist in the adjustment of the binary logit model for the high and low seasons and for Spanish and foreign tourists.

Although this test for conventional structure change (i.e., that based on a classic regression model) has also been used quite frequently in tourism research [74-78], its use with logistic regression models and therefore its contrast through a likelihood ratio test is practically non-existent in tourism research. This work therefore presents a methodological novelty in the field of tourism research.

\section{Results}

\subsection{The Estimated Probability of Practicing Water Tourism in the Bathing Areas of Extremadura}

The results of the model estimation (1) using the Gretl statistics package are shown in Table 2, from which it can initially be appreciated that age is a factor that introduces differences in the probability of practicing inland water tourism in Extremadura. Indeed, the estimated coefficient $\beta$ of the variable AG1 (0.439) and the value clearly greater than 1 of $\exp (\beta)$ (1551) implies that in the case of ceteris paribus, the probability that tourists of 35 years of age or younger will practice this tourism type in the region is significantly higher than for other tourists (the same is not true either of tourists of between 35 and 55 years of age $(\mathrm{AG} 2=1)$ or of tourists over $55(\mathrm{AG} 1=\mathrm{AG} 2=0)$. 
Table 2. Estimation of the binary logistic regression model (1).

\begin{tabular}{|c|c|c|c|c|c|c|c|}
\hline Explanatory Variables & $\beta$ & S.E. & $\mathbf{z}$ & Wald & $p$-Value & Sig. ${ }^{a}$ & $\operatorname{Exp}(\beta)$ \\
\hline GEN & -0.064 & 0.068 & -0.937 & 0.878 & 0.349 & & 0.938 \\
\hline AG1 & 0.439 & 0.104 & 4.201 & 17.645 & $<0.001$ & $* * *$ & 1.551 \\
\hline AG2 & 0.132 & 0.087 & 1.517 & 2.302 & 0.129 & & 1.141 \\
\hline COMP1 & 0.709 & 0.152 & 4.659 & 21.705 & $<0.001$ & $* * *$ & 2.032 \\
\hline COMP2 & 0.359 & 0.166 & 2.155 & 4.645 & 0.031 & $* *$ & 1.431 \\
\hline $\mathrm{H} 1$ & -0.295 & 0.085 & -3.459 & 11.964 & 0.001 & $* * *$ & 0.745 \\
\hline $\mathrm{H} 2$ & 0.484 & 0.102 & 4.727 & 22.342 & $<0.001$ & $* * *$ & 1.622 \\
\hline $\mathrm{H} 3$ & 0.508 & 0.105 & 4.827 & 23.296 & $<0.001$ & $* * *$ & 1.663 \\
\hline VAL_ALOJ & 0.066 & 0.039 & 1.712 & 2.930 & 0.087 & * & 1.068 \\
\hline VAL_REST & -0.039 & 0.038 & -1.027 & 1.055 & 0.304 & & 0.961 \\
\hline VAL_EMP & -0.044 & 0.027 & -1.599 & 2.558 & 0.110 & & 0.957 \\
\hline VAL_NAT & 0.043 & 0.036 & 1.202 & 1.444 & 0.229 & & 1.044 \\
\hline Constant & -2.059 & 0.334 & -6.164 & 37.998 & $<0.001$ & $* * *$ & 0.128 \\
\hline Rat & $\begin{array}{l}\text { Numb } \\
\text { ikelihoo }\end{array}$ & $\begin{array}{r}\text { Log-1 } \\
\text { Schwa } \\
\text { Akail } \\
\text { Hannan- } \\
\text { Mch } \\
\text { r of cases } \\
\text { test: Chi- }\end{array}$ & $\begin{array}{l}\text { hood: }-2 \\
\text { riterion: } \\
\text { iterion: } 5 \\
\text { in criteric } \\
{\text { en's } \mathrm{R}^{2} \text { : }} \text { ectly pre } \\
\text { re }(12 \mathrm{df}\end{array}$ & $\begin{array}{l}.732 \\
9.173 \\
.463 \\
5214.918 \\
14 \\
\text { ed: } 3410 \\
167.287\end{array}$ & $\begin{array}{l}.7 \%) \\
\text { alue: }<0.0\end{array}$ & & \\
\hline
\end{tabular}

a Significant; ${ }^{*}$ Significant at $10 \%$ level; ${ }^{* *}$ Significant at $5 \%$ level; ${ }^{* * *}$ Significant at $1 \%$ level. Source: own work.

Another variable that introduces differences in the probability of practicing inland water tourism is the type of trip. Tourists who travel as a couple or with their family $(\exp (\beta)=2.032)$ are the most likely to practice this type of tourism, followed by those who travel with friends or in a group, while those who travel alone are by far the least likely to be engaged in water tourism activities. Consequently, the eminently family nature of freshwater tourism in the region being analyzed appears to be confirmed.

Thirdly, there is another explanatory variable that introduces noteworthy differences in the probability of practicing water tourism. This is the type of accommodation. Indeed, the parameters of variables $\mathrm{H} 1, \mathrm{H} 2$ and $\mathrm{H} 3$ are all three statistically significant at a level of $1 \%$. However, while the values of $\exp (\beta)$ are clearly greater than 1 in the case of $\mathrm{H} 2$ and $\mathrm{H} 3$, the value of $\exp (\beta)$ for $\mathrm{H} 1$ is much less than 1 . This means, therefore, that the probability of practicing water tourism in the region is significantly higher in the case of ceteris paribus among tourists staying in rural accommodation, apartments, campsites, or hostels than among those staying in hotels or other types of establishment. Consequently, the existence of a clear association between water tourism activities and the use of non-hotel accommodation is confirmed.

Finally, it should be noted that neither gender nor the four destination valuation variables considered in the model significantly affect the probability of practicing water tourism in Extremadura, since its associated parameters are not significant at $1 \%$ or at $5 \%$ (only the VAL_ALOJ variable is significant, but only at a $10 \%$ significance level).

However, the fact of considering the demand for water tourism in Extremadura in an aggregate manner, without differentiating for example between the high and low season on the one hand or between Spanish and foreign tourists on the other hand, may conceal certain statistically significant relationships between some explanatory variables and the probability of practicing water tourism.

It is therefore necessary to introduce the season (high or low) and the origin (Spanish or foreign) of the tourists analyzed as control variables in model (1), in order to determine whether this segmentation of the water tourism demand depending on the season and the origin of tourists results in differentiated behaviors. 


\subsection{Presence/Absence of Structural Change in the Estimation of the Probability of Practicing Water Tourism in Extremadura}

Two control variables $\left(\mathrm{D}_{\mathrm{i}}\right)$ are considered: one to measure the potential influence of the tourism season on the probability of practicing water tourism; the other to determine the effect of the tourism market of origin on this probability. In the case of the tourism season, therefore, the control variable $D_{i}$ has a value of 1 for the high season (the months between April and September) and 0 in all other cases. As for the case of the tourism market of origin, the control variable is given a value of 1 for Spanish tourists and 0 for foreign tourists.

After estimating the model (2) and taking the value of the logarithm of the log-likelihood function of said model while considering the two control variables, the results of the log-likelihood ratio test are presented in Table 3.

Table 3. Results of the log-likelihood ratio test.

\begin{tabular}{cccccc}
\hline Control Variable & $\log \left(\boldsymbol{\Lambda}_{1}\right)$ & $\log \left(\boldsymbol{\Lambda}_{2}\right)$ & $\mathbf{D}$ & d.f. & $\boldsymbol{p}$-Value \\
\hline Season & -2579.732 & -2547.279 & 64.91 & 12 & $<0.0001$ \\
Tourist market & -2579.732 & -2561.714 & 36.04 & 12 & 0.0003 \\
\hline \multicolumn{7}{c}{ d.f. $=$ degrees of freedom. Source: own work. }
\end{tabular}

The results shown in Table 3 clearly identify a structural change in the estimated logit model when considering both the tourism season and the tourist origin market as control variables. Therefore, it can be concluded that the probability of practicing water tourism in Extremadura is significantly different in the high season and in the low season, as could be expected given the different meteorological conditions that occur in each. Similarly, the 'tourism market' control variable also introduces significant differences in the model, since the probability that Spanish tourists practice this type of tourism in the region seems to be different from that of foreign tourists. It is not consequently advisable to design a single tourist promotion campaign aimed at all types of tourists regardless of their origin; campaigns aimed at the foreign market should have different characteristics and connotations from those (which until now have been launched by the Extremadura public tourist administration) aimed at the Spanish market.

\section{Analysis of the Variability of the Estimated Probabilities of Practicing Water Tourism in Terms of the Characteristics of the Tourist Profile}

In order to analyze in greater detail the influence of the control variables previously considered in the estimation of model (1), this model has been re-estimated considering the two groups of observations which in each case determines the existence of the structural change confirmed through the adaptation of the Chow test to the logistic regression model (1). This model has been specifically estimated for the high season (3018 observations) and for the low season (1607 observations). On the other hand, model (1) has also been re-estimated for the Spanish tourists of the sample (4146 observations), and for the foreign tourists of the sample (479 observations). For the four estimated models, and for the sake of simplicity, Table 4 only identifies the explanatory variables of the model that are statistically significant in each case.

Starting with the tourist season, it can be seen that in the high season, most of the variables in the model are statistically significant with a significance level of at least $5 \%$. The only exceptions are the VAL_REST and VAL_NAT variables. Even variables which have not been significant in the global model (1) (the estimate from the global sample) become significant at $5 \%$, when this model is estimated only from data obtained in the high season as is the case of the variable VAL_EMP. On the contrary, when the model is estimated from data obtained in the low season, it can be seen that the explanatory variables are no longer statistically significant. Therefore, when tourism promotion or marketing campaigns are carried out or a segmentation of the water tourism market in Extremadura is desired, based on the probabilities of practicing this type of tourism, for the collection of statistical 
information on which they are based these campaigns will need to take place between the months of April and September, i.e., during the high season.

Table 4. Statistically significant explanatory variables in logit models for (a) high season vs. low season and (b) Spanish tourists vs. national tourists.

\begin{tabular}{ccccc}
\hline Variables & High Season & Low Season & Spanish Tourists & National Tourists \\
\hline GEN & - & - & - & - \\
AG1 & $* * * * * *$ & - & $*$ \\
AG2 & $* *$ & - & - & $* * *$ \\
COMP1 & $* * *$ & - & - & - \\
COMP2 & $* *$ & - & $*$ & $* * *$ \\
H1 & $* * * * * * *$ & - & $*$ \\
H2 & $* * * * * *$ & - & - \\
H3 & $* *$ & - & - & $*$ \\
VAL_ALOJ & - & - & - & - \\
VAL_REST & $* *$ & - & $* *$ & $*$ \\
VAL_EMP & - & $*$ & - & - \\
VAL_NAT & & - & - & $*$
\end{tabular}

* Significant at $10 \%$ level; ${ }^{* *}$ Significant at $5 \%$ level: ${ }^{* * *}$ Significant at $1 \%$ level. Source: own work using Gretl software (Allin F. Cottrell, Winston-Salem, NC, USA).

On the other hand, and now differentiating between the Spanish market and the foreign market, Table 4 also shows clearly that while age, the type of trip, and the type of accommodation are factors which introduce important differences to the probability of practicing water tourism among Spanish tourists, the same is not true when foreign tourists are considered. Even in the two explanatory variables in which significant probability differences have been detected in both markets, the level of significance is always lower in the foreign market ( $5 \%$ in the COMP1 variable, unlike $1 \%$ of this same variable in the Spanish market; $10 \%$ in variable $\mathrm{H} 1$, different from $1 \%$ in the national market).

It is therefore evident that the probability of practicing water tourism will not be the same in the high season as in the low season, because certain factors which condition it in some cases do not do so in others. Hence, it is interesting to compare the histograms of the relative frequencies of these estimated probabilities for the high season and for the low season (Scheme 1). As can be seen, the average estimated probability in the high season ( 0.2926 with a standard deviation of 0.1032$)$ is higher than this same average probability in the low season ( 0.2066 with a standard deviation of 0.0648$)$.
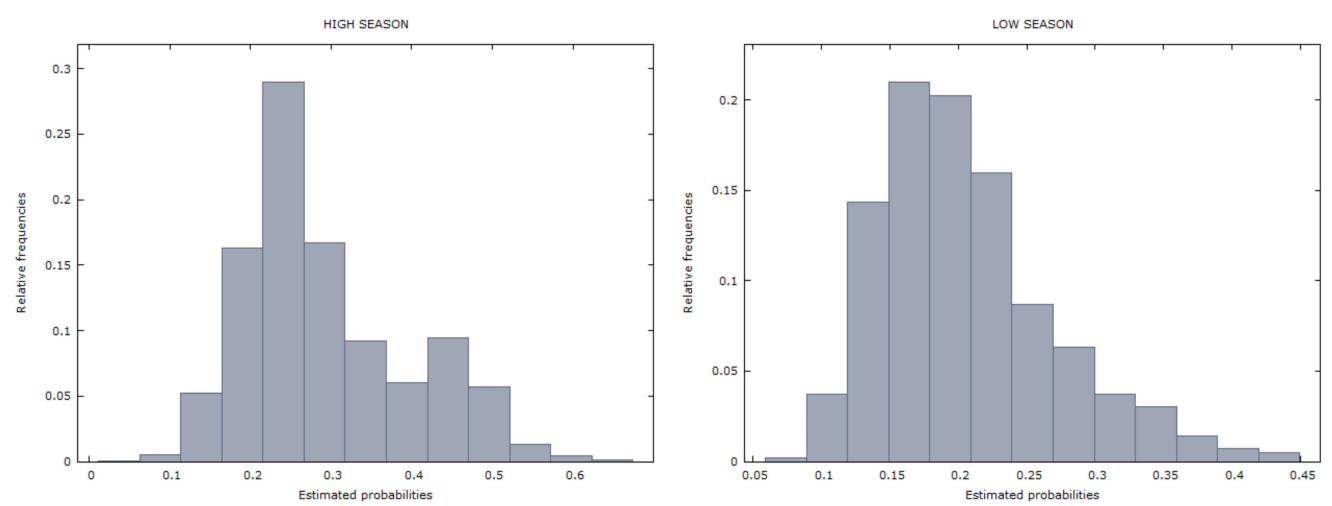

Scheme 1. Comparison of the frequency histogram of the estimated probabilities of practicing water tourism in Extremadura between the high season and the low season.

The situation is similar occurs when we compare the relative frequency histograms (see Scheme 2) of the estimated probabilities for Spanish tourists and for foreign tourists. Thus, while the estimated mean probability for Spanish tourists is 0.2723 (standard deviation: 0.0870 ), for foreign tourists this estimated mean probability is 0.1795 (standard deviation: 0.0974 ). 

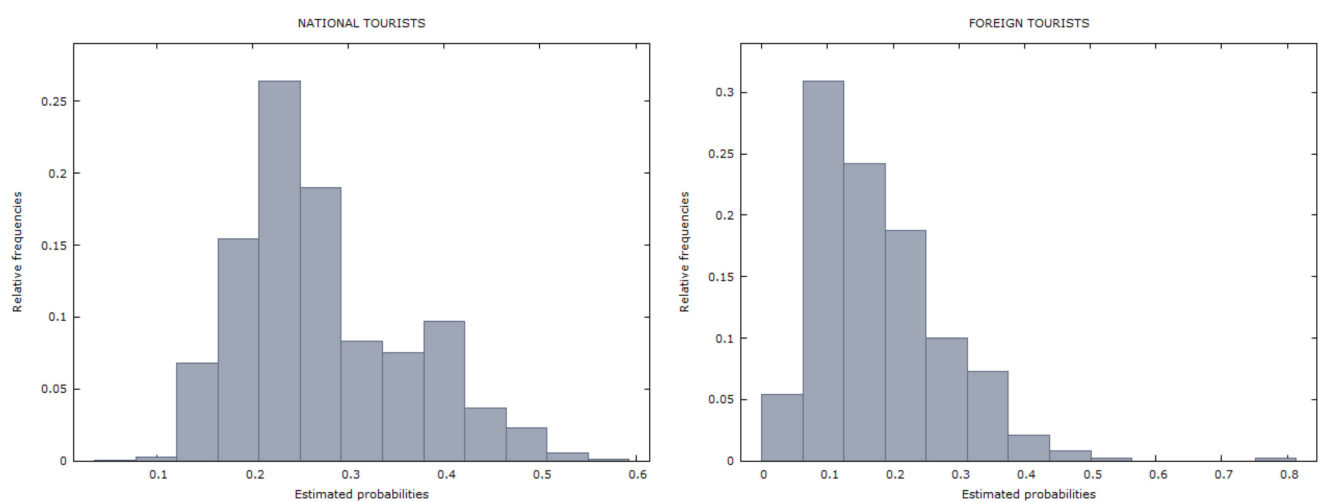

Scheme 2. Comparison of the frequency histogram of the estimated probabilities of practicing water tourism in Extremadura between Spanish tourists and foreign tourists.

Finally, and in order to confirm the effect of the different factors considered on the estimated average probability of practicing inland water tourism in Extremadura, several $t$ tests of equality of means have been carried out, considering as a factor the binary explanatory variables that have been introduced in model (1) and which have turned out to be statistically significant (age, type of trip and type of accommodation). The results of these $t$ tests are presented in Table 5 for the high season and the low season and in Table 5 for the Spanish and foreign market.

Table 5. $T$ tests of equality of the estimated probability of practicing water tourism in Extremadura in the high season and in the low season.

\begin{tabular}{cccccc}
\hline Explanatory Variables & $\begin{array}{c}\text { Average } \\
\text { Low Season }\end{array}$ & $\begin{array}{c}\text { Average } \\
\text { High Season }\end{array}$ & Difference & t Statistics & $p$-Value \\
\hline Aged 35 or younger & 0.2984 & 0.3415 & -0.0431 & -7.92 & $<0.001$ \\
Between 35 and 55 & 0.1850 & 0.3004 & -0.1154 & -40.93 & $<0.001$ \\
Over 55 & 0.1854 & 0.2331 & -0.0477 & -12.82 & $<0.001$ \\
Traveling as a couple or with family & 0.2219 & 0.3136 & -0.0917 & -32.13 & $<0.001$ \\
Traveling with friends or in a group & 0.1775 & 0.2513 & -0.0738 & -15.63 & $<0.001$ \\
Traveling alone & 0.1603 & 0.1896 & -0.0293 & -4.73 & $<0.001$ \\
Staying in hotels & 0.1765 & 0.2179 & -0.0414 & -19.19 & $<0.001$ \\
Staying in rural lodgings & 0.2521 & 0.4298 & -0.1777 & -31.27 & $<0.001$ \\
Staying in apartments, campsites, or hostels & 0.2347 & 0.4121 & -0.1774 & -26.77 & $<0.001$ \\
Staying in other types of establishments & 0.2206 & 0.2667 & -0.0461 & -13.59 & $<0.001$ \\
\hline
\end{tabular}

Source: own work using SPSS software (IBM, Armonk, NY, USA).

In relation to the tourist season, it can be appreciated that the differences in average probabilities are significant in all cases without exception, both $1 \%$ and $5 \%$. Specifically and for the age variable, the most important differences occur between tourists who are between 35 and 55 years old, for whom the probability of practicing water tourism amounts to $30.04 \%$ in the high season; the figure decreases to $18.50 \%$ in the low season. In contrast, for younger and older tourists the differences in probability, although statistically significant, are relatively minor (around a 5\% difference). When considering the type of travel, the clearest differences are found between tourists traveling with their family or as a couple, the average probability of this segment of tourists being estimated at $31.36 \%$ in the high season and $22.19 \%$ in the low season. This difference in probabilities is also almost 8 percentage points between those who travel with friends or in groups, and is considerably less among tourists who travel alone. However, the highest probabilities of practicing water tourism in Extremadura are registered during the high season among those who stay in rural accommodation $(42.98 \%)$ or in apartments, campsites, or hostels (41.21\%). It is also in these types of accommodation where the highest probability differences have been identified in the low season ( $25.21 \%$ and $23.47 \%$, respectively). On the other hand, among tourists who stay in hotels or in other types of tourist accommodation, the probabilities of practicing water tourism in the region are not only lower in both the high and low 
season; the differences in probabilities between both periods, although significant, are much smaller than for other types of accommodation.

Finally, the analysis of the figures presented in Table 6 shows that except in the case of tourists over 55 years of age and those staying in other types of accommodation, the differences in the average probabilities of practicing water tourism in the region between Spanish tourists and foreign tourists are statistically significant. In all cases, the probability is always higher among the former than among the latter. In the specific case of age, the greatest differences occur between those aged between 35 and 55 years old, since among Spanish tourists this probability rises to 0.2738 , while among foreigners this average probability is only $14.34 \%$. Important differences in probabilities are also detected among younger tourists (33.49\% for domestic tourists; $23.61 \%$ for foreigners). If we consider the way of traveling, the most important differences occur between tourists traveling alone, since the estimated average probability for foreign tourists is only $9.09 \%$ (the lowest of all calculated), while in the case of Spanish tourists this average probability amounts to $20.0 \%$. In any case, the highest average probabilities are determined once by the type of accommodation. Thus, while national tourists staying in apartments, campsites, or hostels register an average probability of $38.91 \%$ (and those who do so in rural accommodation of $37.50 \%$ ), foreign tourists staying in these two types of accommodation present an average probability of practicing water tourism in Extremadura of $25.64 \%$ and $18.42 \%$, respectively.

Table 6. $T$ tests of equality of the estimated probabilities of practicing water tourism in Extremadura for Spanish tourists and for foreign tourists.

\begin{tabular}{|c|c|c|c|c|c|}
\hline Explanatory Variables & $\begin{array}{l}\text { Average } \\
\text { Foreign }\end{array}$ & $\begin{array}{l}\text { Average } \\
\text { Domestic }\end{array}$ & Difference & t Statistics & $p$-Value \\
\hline Aged 35 or younger & 0.2361 & 0.3349 & -0.0988 & -8.92 & $<0.001$ \\
\hline Between 35 and 55 & 0.1434 & 0.2738 & -0.1304 & -21.69 & $<0.001$ \\
\hline Over 55 & 0.2183 & 0.2155 & 0.0028 & 0.29 & 0.765 \\
\hline Traveling as a couple or with family & 0.1993 & 0.2912 & -0.919 & -17.72 & $<0.001$ \\
\hline Traveling with friends or in a group & 0.1881 & 0.2290 & -0.0409 & -4.33 & $<0.001$ \\
\hline Traveling alone & 0.0909 & 0.2000 & -0.1091 & -17.75 & $<0.001$ \\
\hline Staying in hotels & 0.1336 & 0.2103 & -0.0767 & -20.96 & $<0.001$ \\
\hline Staying in rural lodgings & 0.2564 & 0.3750 & -0.1186 & -7.83 & $<0.001$ \\
\hline Staying in apartments, campsites, or hostels & 0.1842 & 0.3891 & -0.2049 & -18.48 & $<0.001$ \\
\hline Staying in other types of establishments & 0.2385 & 0.2548 & -0.0163 & -1.66 & 0.099 \\
\hline
\end{tabular}

Source: own work using SPSS software.

\section{Conclusions}

Inland water tourism is currently a strategic option that allows territories to achieve economic development in a sustainable manner by designing tourist products based on their lake resources. In this sense, inland destinations have a good opportunity to put themselves on the tourist map, especially those territories that are characterized by having a large number of aquifer systems, as is the case of the region of Extremadura.

The slogan "Extremadura is Water", used by tourism managers in the region, is a declaration of intent that demonstrates the decision to make water tourism the flagship of the tourism offer of the region. The excellent availability of existing expanses of water, together with the potential attributable to this tourist product of generating sustainable economic growth for the destination and the situation that the region presents, characterized by a high dependence on the primary sector and being among the most depressed areas of Spain in terms of GDP per capita, seem compelling reasons to put our faith in this orientation.

In order to achieve the objectives pursued, to manage the available resources efficiently, and to implement strategic planning, which makes it possible to make the region a future benchmark for inland water tourism, information on this tourist market must be obtained. Aspects such as what its sociodemographic characteristics are, when these trips are made, what type of trip they take, or what is the accommodation type preferred by inland water tourists, among others, are questions that become 
variables of interest in order to become familiar with and understand this demand. In addition, it should be borne in mind that these variables have great distinguishing power and help to ensure correct market segmentation; characterizing demand is therefore an important tool for tourism managers.

Despite the usefulness of this information, by conducting this research it has been found that to date, in the case of Spain, little attention has been paid to drawing up the profile of the demand for this specific type. For this reason, the objective of this research is identifying which characteristics affect the probability of tourists who visit Extremadura practicing an inland water tourism activity.

Regarding the main theoretical implications, it should be noted that the results obtained have allowed us to confirm that this tourist practice is more likely among young people (under 35 years of age) traveling with their partner or friends to their destination. These results are in line with those obtained by Albayrak and Caber [15], who found that the profile with the greatest importance among rafting participants in Antalya, Turkey, was that of young people who made the trip with their families. However, this finding contrasts with the results obtained in the previous study carried out in the same region under study [16], in which it was clearly identified that the predominant profile for this category was that of women over 55 years of age. This difference may be explained by the strong presence in the sample used in the aforementioned study of the thermal or spa tourist, since, of the 184 surveys carried out, a total of 167 correspond to tourists visiting spas, who traditionally have an older profile.

The structural change test has allowed us to find out the probability of practicing inland water tourism and the characteristics associated with it vary depending on the type of market and the tourist season. Regarding the tourist season, as expected it was found that the practice of this activity is more likely during the high season. Indeed, its marked seasonality is one of the negative factors of this tourist activity and is likewise one of the distinctive features of the tourism sector in Spain [3]. Therefore, in order to minimize the possible adverse effects associated with fluctuating demand, it is essential to offer tourism products associated with the resources that allow tourism to be practiced at any time of the year.

As far as the market type is concerned, that of Spanish tourists is of greater importance among the participants of this tourist type in the region. The smaller contribution of foreign tourists had already been confirmed in previous studies carried out in the region, the results of which showed a low presence of foreign tourists among visitors to water tourism establishments [16]. In addition, it should be noted that the results obtained by this research confirm that the probability of practicing inland water tourism in the case of Spanish tourists is more than 10 points higher than that obtained for foreigners $(0.2723$ vs. 0.1795$)$. Therefore, we need to know the reasons why water tourism is not turning out to be equally attractive to foreign visitors in order to design more attractive products for this market, which would increase the potential target of water tourism in the region of Extremadura.

Addressing specifically some of the practical implications derived from the results achieved, it should be noted that, as already mentioned, inland water tourism, although it may be an alternative for the "sun and beach" product, has in common with it a high seasonality compared to other tourist products. For this reason, destination managers have to be aware of this reality by designing products around their lake resources that are suitable for the different seasons of the year in order to reduce this fluctuation in demand. From the results of this study, it is extracted that it is the young public, on the other hand, in this regard, the profile of the young tourist who travels in a group or with friends is positioned as the most attractive in this sense, since it is the profile that presents the greatest probability of doing this practice, and at the same time, is the one that presents the least variation between seasons. For this reason, this tourist should be outlined as a priority to be captured in the strategic planning of inland water tourism products.

In addition, it should be borne in mind that the accommodation chosen for the most part is rural accommodation. This can be explained by the location of the lake resources, mostly found in the natural or rural environment, in which this type of accommodation predominates. The managers of these accommodations must be aware of this reality and design their promotional campaigns strongly linked, among others, to this tourist product. 
On the other hand, it has been verified that this sector in the Extremadura region has a strong dependence on resident tourism, so it would be convenient to diversify demand to a more international public. In this way, the dependence of the sector on the good performance of the national economy would be softened, while allowing the current size of the market to be expanded. In this sense, it would be convenient for the regional administration to target the international markets in order to research what their needs are and to be able to design and adapt products that may be attractive to them. At the same time, it would be essential to promote the destination in these markets to try to capture an audience that allows expanding the current size of the demand for inland water tourism.

Finally, the structural change test has revealed that there are significant differences in demand with the two control variables introduced; that is, depending on both the season and the market of origin. For this reason, the planning carried out in the sector must take this characteristic into account in order to design both the planning of the sector and the different communication campaigns in order to achieve the pursued objectives more efficiently. To conclude, the main limitations of this applied research include: On the one hand, the specificity of the context analyzed implies the need for caution in extrapolating the results to other destinations. For the aforementioned reason, as a future line of research, we propose repeating this study in tourist destinations with characteristics similar to that used as the objective in this research, so that the results can be compared in order to enrich the conclusions obtained by comparing them. And on the other hand, the importance of expanding both the geographical spectrum of the analyses to varied destinations and the selection of variables used among the determining factors of the option should not be overlooked in the future when researching this type of tourism. In the latter case, environmental awareness can be mentioned together with the relevance given to the various opportunities offered by environments with water resources among others.

Author Contributions: Conceptualization, M.S.-R., M.C.R.-R. and Y.F.-T.; methodology, M.S.-R., M.C.R.-R. and Y.F.-T.; software, M.S.-R., M.C.R.-R. and Y.F.-T.; validation, M.S.-R., M.C.R.-R. and Y.F.-T.; formal analysis, M.S.-R., M.C.R.-R. and Y.F.-T.; investigation, M.S.-R., M.C.R.-R. and Y.F.-T.; resources, M.S.-R., M.C.R.-R. and Y.F.-T.; data curation, M.S.-R., M.C.R.-R. and Y.F.-T.; writing-original draft preparation, M.S.-R., M.C.R.-R. and Y.F.-T.; writing-review and editing, M.S.-R., M.C.R.-R. and Y.F.-T.; visualization, M.S.-R., M.C.R.-R. and Y.F.-T.; supervision, M.S.-R., M.C.R.-R. and Y.F.-T.; project administration, M.S.-R.; funding acquisition, M.S.-R. All authors have read and agreed to the published version of the manuscript.

Funding: This research was supported by the Junta of Extremadura and was co-financed by the European Regional Development Fund through projects IB18015.

Conflicts of Interest: The authors declare no conflict of interest. The funders had no role in the design of the study; in the collection, analyses, or interpretation of data; in the writing of the manuscript, or in the decision to publish the results.

\section{References}

1. The World Tourism Organization. Tourism and Sustainable Development Goals-Journey to 2030. Available online: https://www.unwto.org/global/publication/tourism-and-sustainable-developmentgoals-journey-2030 (accessed on 4 May 2020).

2. Li, H.; Goh, C.; Zhan, Q.H.; Meng, F. Effect of tourism on balanced regional development: A dynamic panel data analysis in costal inland China. Asia Pac. J. Tour. 2015, 20, 694-713. [CrossRef]

3. Guzmán-Parra, V.F.; Quintana-García, C.; Benavides-Velasco, C.A.; Vila-Oblitas, J.R. Trends and seasonal variation of tourist demand in Spain. The role of rural tourism. Tour. Manag. Perspect. 2015, 16, 123-128. [CrossRef]

4. Díez, D. Los turismo de interior: Un enfoque desde la dimensión de las modalidades turístico-recreativas. Doc. Anál. Geog. 2012, 58, 373-396. [CrossRef]

5. Reguero, M. Ecoturismo. In Nuevas Formas de Turismo en el Espacio Rural; Bosch Turismo: Barcelona, España, 1994; ISBN 978-8-476-76286-8.

6. Mediano, L. La Gestión del Marketing en el Turismo Rural; Pearson Educación-Prentice: Madrid, España, 2004; ISBN 978-8-420-54090-0. 
7. Romão, J.; Guerreiro, J.; Rodrigues, P. Regional tourism development: Culture, nature, life cycle and attractiveness. Curr. Issue Tour. 2013, 16, 517-534. [CrossRef]

8. Hadwen, W.L.; Boon, P.I.; Arthington, A.H. Aquatic ecosystems in inland Australia: Tourism and recreational significance, ecological impacts and imperatives for management. Mar. Freshw. Res. 2012, 63, 325-340. [CrossRef]

9. Berezin, A. A- Aquatic realms and running water in sustainable tourism. In Environmental Impacts; Brebbia, C.A., Chon, T.S., Eds.; WIT Press: Southampton, UK, 2012; pp. 447-458, ISBN 978-1-845-64604-2.

10. Olsson, A.K. Canals, rivers and lakes as experiencescapes-destination development based on strategic use of inland water. Int. J. Entrepr. Small Bus. 2016, 29, 217-243. [CrossRef]

11. Erfurt-Cooper, P. European waterways as a source of leisure and recreation. In River Tourism; Prideaux, B., Cooper, M., Eds.; CABI: Wallingford, UK, 2009; pp. 95-117, ISBN 978-1-845-93468-2.

12. Hall, C.M.; Härkönen, T. Lake Tourism: An Integrated Approach to Lacustrine Tourism Systems; Channel View Publications: Clevedon, UK, 2006; ISBN 978-1-845-41041-4.

13. Osning, N.A.; Rahman, N.S.F.A. Assessment and ranking of inland navigation practices in Malaysia: The case of Kenyir lake. Asian J. Shipp. Logist. 2018, 34, 289-296. [CrossRef]

14. Galloway, S. Recreation Specialisation among New Zealand whitewater kayakers: A study of motivation and site preference. Ann. Leis. Res. 2011, 13, 523-540. [CrossRef]

15. Albayrak, T.; Caber, M. A motivation based segmentation of holiday tourists participating in white-water rafting. J. Destin. Mark. Manag. 2018, 9, 64-71. [CrossRef]

16. Folgado-Fernández, J.A.; Di-Clemente, E.; Hernández-Mogollón, J.M.; Campón-Cerro, A.M. Water Tourism: A New Strategy for the Sustainable Management of Water-Based Ecosystems and Landscape in Extremadura (Spain). Land 2019, 8, 2. [CrossRef]

17. Extremadura, Agua Dulce (REDEX). Available online: https://redex.org/ficheros/archivos/2017_08/173-folletoagua.pdf (accessed on 4 May 2020).

18. Andrades, L. Planificación turística y sostenible. Aplicación a un destino de costa interior de Extremadura: El embalse de La Serena. Rev. Estud. Empres. 2008, 2, 24-47. Available online: https://revistaselectronicas. ujaen.es/index.php/REE/article/view/364 (accessed on 4 May 2020).

19. Chow, G.C. Tests of equality between sets of coefficients in two linear regressions. Econometrica 1960, 28, 591-605. [CrossRef]

20. UNWTO. World Tourism Organization Tourism Highlight 2017. Available online: http://www.e-unwto.org/ doi/pdf/10.18111/9789284419029 (accessed on 4 May 2020).

21. Wang, Y.; Pizam, A. Tourism Destination Marketing and Management: Collaborative Strategies; CABI: Wallingford, UK, 2011; ISBN 978-1-84593-762-1.

22. Honadle, B.W. Extension and tourism development. J. Ext. 1990, 28. Available online: https://www.joe.org/ joe/1990summer/a1.php (accessed on 9 June 2020).

23. Araque, E.; Sánchez-Martínez, J.D.; Cantarero, J.M. Cazorla, Segura y las Villas: Oportunidades para la reconstrucción sostenible de un espacio turístico de interior. Cuad. Tur. 2002, 10, 85-100. Available online: https://revistas.um.es/turismo/article/view/21851 (accessed on 4 May 2020).

24. Schroeder, T. Motivations of resource-based tourism operators in North Dakota. J. Ext. 2004, 42. Available online: https://www.joe.org/joe/2004december/a6.php (accessed on 9 June 2020).

25. Tweeten, K.; Leistritz, L.; Hodur, N. Growing rural tourism opportunities. J. Ext. 2008, 46. Available online: https://www.joe.org/joe/2008april/a2.php (accessed on 9 June 2020).

26. López, J. El Turismo Ornitológico en el Marco del Postfordismo, Una Aproximación Teórico-Conceptual. Cuad. Tur. 2008, 21, 85-111. Available online: https://revistas.um.es/turismo/article/view/25001 (accessed on 4 May 2020).

27. Marcouiler, D.; Coggins, S. Water Issues in Wisconsin-The Economic Value of Water: An Introduction. Wisconsin Extension, University of Wisconsin 1999. Available online: https://www.uwsp.edu/cnrap/UWEXLakes/Documents/people/economics/07_econValueIntro_marcouiller_paper.pdf (accessed on 4 May 2020). 
28. Otto, D.L.; Monchuck, D.C.; Barr, K.J.; Kling, C.L. The Economic Valur of Iowa's Natural Resources 2007. Available online: https://www.semanticscholar.org/paper/The-Economic-Value-of-Iowa\T1\textquoterightsNatural-Resources-Otto-Monchuck/7ddddb1623a62aff41c961785b1da0bf15fef761 (accessed on 4 May 2020).

29. Oladele, O.I. Knowledge levels and perceived effect of ecosystem services and valuation on extension delivery in North West Province, South Africa. J. Int. Agric. Ext Educ. 2012, 19, 42-53. [CrossRef]

30. Blamey, R.; Hatch, D. Profiles and motivations of nature-based tourists visiting Australia. Bur. Tour. Res. 1998, 25, 75.

31. Carr, A. Lakes, myths and legends: The relationship between tourism and cultural values for water in Aotearoa. In Lake Tourism and Integrated Approach to Lacustrine Tourism System; Hall, C., Härkönen, T., Eds.; Channel View Publications: Clevedon, UK, 2006; pp. 83-100, ISBN 978-1-845-41040-7.

32. Tuohino, A. Lakes as an opportunity for tourism marketing: In search of the spirit of the lake. In Lake Tourism and Integrated Approach to Lacustrine Tourism System; Hall, C., Härkönen, T., Eds.; Channel View Publications: Clevedon, UK, 2006; pp. 101-118, ISBN 978-1-845-41040-7.

33. Mosisch, T.D.; Arthington, A.H. A review of literature examining the effects of water-based, powered recreational activities on lakes and rivers. Lakes and Reservoirs. Res. Manag. 1998, 3, 1-17.

34. Mosisch, T.D.; Arthington, A.H. Impacts of recreational power-boating on freshwater ecosystems. In Environmental Impacts of Ecotourism; Buckley, R., Ed.; CABI Publishing: Wallingford, UK, 2004; pp. 125-154, ISBN 978-0-851-99810-7.

35. García, L. Agua y turismo. Nuevos usos de los recursos hídricos en la Península Ibérica. Enfoque Integral. BAGE 2004, 37, 239-255.

36. Costa, C.; Quintela, J.; Mendes, J. Health and wellness tourism: A strategic plan for tourism and thermalism valorization of São Pedro do Sul. In Health and Wellness Tourism; Peris-Ortiz, M., Álvarez-García, J., Eds.; Springer: Cham, Switzerland, 2015; pp. 21-31, ISBN 978-3-319-38525-9.

37. Pueyo-Ros, J. The role of tourism in the ecosystem services framework. Land 2018, 7, 111. [CrossRef]

38. Diputación de Badajoz. Available online: http://turismo.badajoz.es/es/recursoturistico/lago_alqueva (accessed on 4 May 2020).

39. Visit Portugal. Available online: https://www.visitportugal.com/es/content/alqueva (accessed on 4 May 2020).

40. AlquevaRural.com. Available online: http://alquevarural.com/ (accessed on 4 May 2020).

41. National Geographic. Available online: https:/viajes.nationalgeographic.com.es/a/viaje-a-suiza-lago-lemana-alpes_10993 (accessed on 4 May 2020).

42. France-Voyage.com. Available online: https://www.france-voyage.com/francia-guia-turismo/lago-leman467.htm (accessed on 4 May 2020).

43. Agenzia Nazionale Turismo Italia. Available online: http://www.italia.it (accessed on 4 May 2020).

44. VisitNorway. Available online: https://www.visitnorway.es/que-ver-en-noruega/noruega-de-los-fiordos/ sognefjord/ (accessed on 4 May 2020).

45. Sognefjord.no. Available online: https://es.sognefjord.no/ (accessed on 4 May 2020).

46. Nicolau, J.L.; Más, F.J. Sequential choice behaviour: Going on vacation and type of destination. Tour. Manag. 2008, 29, 1023-1034. [CrossRef]

47. Cánoves, G.; Villarino, M.; Blanco, A.; De Uña, E.; Espejo, C. Turismo de Interior: Renovarse o Morir. Estrategias y Productos en Calalunya, Galicia y Murcia; Publicaciones de la Universidad de Valencia: Valencia, Spain, 2014.

48. Borisova, T.; Bi, X.; Larkin, S.; Longanecker, J. Assessing nature-based recreation to support economic development and environmental sustainability extension programs. J. Ext. 2016, 54. Available online: https://www.joe.org/.../rb1.php (accessed on 22 February 2020).

49. Carballo, R.; Fraiz, J.A.; Araújo, N.; Rivo, E. Segmentación del mercado de un destino turístico de interior. El caso de A Ribeira Sacra (Ourense). Pasos. Rev. Tur. Patrim. Cultur. 2016, 14, 369-383. [CrossRef]

50. Paco, A.; Martinho, M. Market segmentation: An application to the Schist village tourism destination. Mark. Tržište 2017, 29, 205-218. [CrossRef] 
51. Hernández, J.M.; Suárez-Vega, R.; Santana-Jiménez, Y. The inter-relationship between rural and mass tourism. The case of Catalonia, Spain. Tour. Manag. 2016, 54, 43-57. [CrossRef]

52. Kruger, L.E. Writing of water and recreation. J. Park Recreat. Adm. 2017, 35, 121-123. Available online: https://www.fs.fed.us/pnw/pubs/journals/pnw_2017_kruger002.pdf (accessed on 3 May 2020).

53. Sánchez-Martín, J.M.; Sánchez-Rivero, M.; Rengifo-Gallego, J.I. La evaluación del potencial para el desarrollo del turismo rural. Aplicación metodológica sobre la provincia de Cáceres. GeoFocus. Rev. Int. Cienc. Tecnol. Inf. Geogr. 2013, 13, 99-130. Available online: http://hdl.handle.net/10662/8708 (accessed on 1 May 2020).

54. Instituto Nacional de Estadística (INE). Available online: https://www.ine.es/dyngs/INEbase/es/operacion. htm?c=Estadistica_C\&cid=1254736167628\&menu=ultiDatos\&idp=1254735576581 (accessed on 4 May 2020).

55. Encuesta de Población Activa (EPA). Available online: https://www.ine.es/dyngs/INEbase/es/operacion.htm? c=Estadistica_C\&cid=1254736176918\&menu=resultados\&idp=1254735976595 (accessed on 4 May 2020).

56. Blue Flag 2019. Available online: http://www.banderaazul.org/sites/default/files/2019/RuedaPrensa2019/ RELACION_DE_PLAYAS_GALARDONADAS_BA2019.pdf (accessed on 4 May 2020).

57. Andrades, L. Planificación turística y recreacional sostenible para el embalse de Alqueva en su margen español. Rev. Anal. Tur. 2010, 10, 23-33. [CrossRef]

58. Franco, A.; Zhu, X. Water markets: Insights from an applied general equilibrium model for Extremadura, Spain. Water Resour. Manag. 2015, 29, 4335-4356. [CrossRef]

59. Sánchez, M.; Rodríguez, C.; Andrades, L. Analysis of spa tourist motivations: A segmentation approach based on discriminant analysis. Enligh. Tour. A Path. J. 2016, 1, 19-43. Available online: http://hdl.handle. net/10272/12443 (accessed on 2 May 2020).

60. Campesinos, A.J. Paisajes del agua y turismo fluvial en la Raya Ibéria. In Paisaje, Cultura Territorial y Vivencia de la Geografía; Vera, J.F., Olcina, J., Hernández, M., Eds.; Publicaciones de la Universidad de Alicante: San Vicente del Raspeig, España, 2016; pp. 47-72, ISBN 978-8-41672-403-1.

61. Peng, C.Y.; So, T.S.H. Logistic regression analysis: A premier. Undert. Stat. 2002, 1, 31-70. [CrossRef]

62. Cameron, A.; Trivedi, P. Micro Econometrics: Methods and Applications; Cambridge University Press: Cambridge, UK, 2005; ISBN 978-0-511-12367-2.

63. Wooldridge, J.M. Introductory Econometrics: A Modern Approach, 5th ed.; South-Western: Mason, OH, USA, 2012; ISBN 978-1-111-53104-1.

64. Morley, C. Technique and theory in tourism analysis. Tour. Econ. 2012, 18, 1273-1286. [CrossRef]

65. Divisekera, S.; Nguyen, V.K. Determinants of innovation in tourism evidence from Australia. Tour. Manag. 2018, 67, 157-167. [CrossRef]

66. Nordli, A.J. Information use and working methods as drivers of innovation in tourism companies. Scand. J. Hosp. Tour. 2018, 18, 199-213. [CrossRef]

67. Li, M.; Fang, L.; Huang, X.; Goh, C. A spatial-temporal analysis of hotels in urban tourism destination. Int. J. Hosp. Mang. 2015, 45, 34-43. [CrossRef] [PubMed]

68. Pagliara, F.; La Pietra, A.; Gómez, J.; Vasallo, J.M. High Speed Rail and the tourism market: Evidence from the Madrid case study. Transp. Policy 2015, 37, 187-194. [CrossRef]

69. Frisvol, S.; Fosbord, M.; Blekesaune, A. An empirical investigation of tourists'consumption of local food in rural tourism. Scand. J. Hosp. Tour. 2016, 16, 76-93. [CrossRef]

70. Sabbatini, V.; Manthoulis, G.; Baourakis, G.; Drakos, P.; Angelakis, G.; Zopounidis, C. Tourists behavioural analysis on olive oil consumption: Empirical results. Int. J. Tour. Pol. 2016, 6, 136-146. [CrossRef]

71. Bucur, E.; Danet, A.F.; Lehr, C.B.; Lehr, E.; Nita-Lazar, M. Binary logistic regression-Instrument for assessing museum indoor air impact on exhibits. J. Air Waste. Manag. Assoc. 2017, 67, 391-401. [CrossRef] [PubMed]

72. Frangos, C.C.; Karapistolis, D.; Stalidis, G.; Fragkis, C.; Sotiropoulos, I.; Manolopoulos, I. Tourist loyalty is all about prices, culture and the sun: A multinomial logistic regression of tourists visiting Athens. Procedia Soc. Behav. Sci. 2015, 175, 32-38. [CrossRef]

73. Wilk, S.S. The large-sample distribution of the likelihood ratio for testing composite hypotheses. Ann. Math. Stat. 1938, 9, 60-62. Available online: https://www.jstor.org/stable/2957648 (accessed on 15 April 2020). [CrossRef] 
74. Arfa, F.; Kaboli, S.; Yazdanfar, S.A.; Mohammadi, H. The effective factors of increasing visits of international tourists to a recognized cultural or natural heritage in UNESCO World Heritage List. Int. J. Hum. Cult. Stud. 2016, 1353-1363; ISSN 2356-5926. Available online: https://www.ijhcs.com/index.php/ijhcs/article/viewFile/ 1523/1366 (accessed on 2 May 2020).

75. Anggraeni, G.N. The relationship between numbers of international tourist arrival and economic growth in the Asean-8: Panel data approach. J. Develop. Econ. 2017, 1, 40-49. [CrossRef]

76. Rodríguez, C.; Sánchez, M. Análisis de las páginas webs de los espacios naturales como destinos turísticos a través del modelo de Rasch: Una aplicación al caso de Rusia. Rev. Anál. Tur. 2014, 18, 33-43. [CrossRef]

77. Holik, A. Relationship of economic growth with tourism sector. J. Eco. Pol. 2016, 9, 16-33. [CrossRef]

78. Gunter, U.; Smeral, E. European outbound tourism in times of economic stagnation. Int. J. Tour. Res. 2016, 19, 269-277. [CrossRef]

(C) 2020 by the authors. Licensee MDPI, Basel, Switzerland. This article is an open access article distributed under the terms and conditions of the Creative Commons Attribution (CC BY) license (http://creativecommons.org/licenses/by/4.0/). 